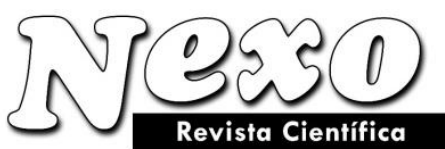

Vol. 34, No. 01, pp. 330-345/Marzo 2021

\title{
On the historical development of the phonetic system of english: a linguosynergetic approach
}

\section{Sobre el desarrollo histórico del sistema fonético del inglés: un enfoque lingüístico-sinérgico}

\author{
Tetiana I. Dombrovan ${ }^{1, *}$, Olena M. Mitina ${ }^{1}$, Lada M. Rostomova ${ }^{1}$, Iryna V. Slobodzowa ${ }^{2}$, \\ Khrystyna T. Pavliuk ${ }^{1}$ \\ ${ }^{1}$ Odessa National Polytechnic University. Department of English Philology and Translation Studies. \\ Odesa, Ukraine. \\ ${ }^{2}$ Odessa National Polytechnic University. Department of German Philology and Translation Studies. \\ Odesa, Ukraine. \\ *dombrovan5514-2-4@uoel.uk
}

(recibido/received: 23-October-2020; aceptado/accepted: 17-December-2020)

\begin{abstract}
The article advances a novel methodological approach to the study of language development, namely a diachronic synergetics. The purpose of the present research is, through disclosing synergetic features of the phonetic system, to reveal heuristic potency and applicability of principles of the synergetic paradigm to language studies. The authors claim that the phonetic system of language possesses synergetic features and it changes according to common principles of development of complex systems. The authors prove that changes in the phonetic system are neither chaotic nor random, since they are preconditioned by the features of the system itself. The theoretical significance of the present research lies in the widening of our knowledge of language as a synergetic system, and of synergetic features of the phonetic system of English, in particular. The obtained data can be fully employed practically into lectures and seminars on the history of English, theoretical phonetics, and historical linguistics.
\end{abstract}

Keywords: History of language; Language development; Phonetic system; Synergetic system.

\section{RESUMEN}

El artículo presenta un enfoque metodológico novedoso para el estudio del desarrollo del lenguaje, a saber, una sinergia diacrónica. El propósito de la presente investigación es, mediante la divulgación de las características sinérgicas del sistema fonético, revelar la potencia heurística y la aplicabilidad de los principios del paradigma sinérgico a los estudios del lenguaje. Los autores afirman que el sistema fonético del lenguaje posee características sinérgicas y cambia de acuerdo con principios comunes de desarrollo de sistemas complejos. Los autores prueban que los cambios en el sistema fonético no son caóticos ni aleatorios, ya que están precondicionados por las características del propio sistema. La importancia teórica de la presente investigación radica en la ampliación de nuestro conocimiento del lenguaje como sistema sinérgico, en general, y de los rasgos sinérgicos del sistema fonético del inglés, en particular. Los datos 
obtenidos se pueden emplear en su totalidad de forma práctica en conferencias y seminarios sobre la historia del inglés, la fonética teórica y la lingüística histórica.

Palabras claves: Historia del lenguaje; Desarrollo del lenguaje; Sistema fonético; Sistema sinérgico.

\section{INTRODUCTION}

We live in a world of systems. Small and tiny, large and enormous. The whole Universe is a super-megasystem of sub-systems containing smaller systems fractally-built and coherently interconnected. Everything around us can be considered a system, or, to be more precise, a system of systems. For instance, any society (a system itself) embraces smaller systems, such as a governmental system, a political system, a system of education, a system of medical care, a transport system, to mention just a few; and being a system, it is included in systemic relations with other societies of the world. Another example is a human body: it consists of a lymphatic system, a circulatory system, a digestive system, a nervous system, and so on. All the systems are closely connected and interdependent: a change within one system may influence the behaviour of another (the so-called "butterfly effect").

The systemic-thinking approach as a comprehensive world view was initially articulated by biologist L. von Bertalanffy (1968), who is generally acknowledged as the founder of General Systems Theory (GST) in the middle of the 20th century (Bertalanffy and Sutherland, 1974). GST was described as a philosophy of synthesis based on interdisciplinarity. In 1968 Bertalanffy wrote that "there exist models, principles, and laws that apply to generalized systems or their subclasses, irrespective of their particular kind, the nature of their component elements, and the relations or "forces" between them. It seems legitimate to ask for a theory, ... of universal principles applying to systems in general. In this way we postulate a new discipline called General System Theory. Its subject matter is the formulation and derivation of those principles which are valid for "systems" in general".

GST, alongside cybernetics and a number of scientific theories (such as Quantum Theory, Irreversible Thermodynamics Theory, Instability Theory, Dynamic Chaos Theory, Catastrophe Theory, PhaseTransition Theory, the Theory of Bifurcations, the Theory of Autowave Processes, the Theory of Oscillation, and others) brought about our understanding of the ubiquity of systems and provided a foundation for synergetics as a unified approach to various complex systems study. The term "synergetics" (from Greek "coherent action") was introduced by the German physicist Hermann Haken (1977; 1987; 2000) to name a science of complexity, dealing with principles of emergence, self-organisation and selfregulation of complex systems of various ontologies - either man-made (artificial) or natural (selforganised). Notions of synergetics are applicable to language study as well, because a human language is also a system. To be more precise, it is a system of systems, too, hierarchically embedded and interconnected.

Traditionally, linguists distinguish between a phonetic system, a lexical system, a syntactic system, a system of the word's meanings, etc. The subject of this article is the phonetic system of English. The purpose of the present research is, through disclosing synergetic features of the phonetic system, to reveal heuristic potency and applicability of principles of the synergetic paradigm to language studies.

To achieve the purpose, the following tasks are to be considered and solved:

- $\quad$ to outline the notion of a synergetic system;

- $\quad$ to consider from a synergetic perspective the historical processes within the system of vowels;

- $\quad$ to study historical changes within consonants. 
The theoretical significance of the present research lies in the widening of our knowledge of language as a synergetic system, on the whole, and of the phonetic system of English, in particular. It is argued that the phonetic system of language (in our case - of English) has characteristics of a synergetic system, and as such, it evolves according to the common principles of a system's development. The obtained data can be fully employed practically into lectures and seminars on the history of English, theoretical phonetics, historical linguistics, etc.

\section{MATERIALS AND METHODS}

Since we research into the historical development of the English language, the material for the present investigation embraces a wide time span - from Old English to Modern English with a special emphasis on the transition stage during Middle English. We analyse Old English prose and verse texts collected in (Mitchell and Robinson, 1997). The samples of Middle English texts include The Canterbury Tales by G. Chaucer (1996) and others are taken from (Burrow and Turville-Petre, 1997). At times, we suggest reanalysis of phonetic phenomena discussed in text-books and scientific articles on the history of English listed in bibliography.

This investigation is based on the following scientific methods: the descriptive method (to describe the corpus of the material), the method of analysis and synthesis closely connected with the inductive and deductive methods (in order to analyze the linguistic facts and infer conclusions), the method of modelling (to represent schematically the subject of the study). Our research fully employs concepts of synergetics a study of complexity.

Synergetics is seen as a specific theoretical and methodological platform, systematising numerous fragments of knowledge about the external world obtained by science and integrating them into a comprehensive image of the world. A synergetic view of the world represents the latter as capable of self-organising from parts into unity. This calls to mind a hologram, in which the whole can be restored from any of its fragments. The holographic model of the world is supported by a philosophical understanding of the wholeness of the physical matter and may be regarded as a next stage in the never-ending evolution of the Universe. The Universe constitutes a total dynamic superstructure of limitless variety of criss-crossed powerful megasystems developing in a non-linear way and changing according to their own inner laws and purposes.

The article advances a new multidisciplinary approach to language studies - namely, diachronic linguosynergetics, focusing on principles and mechanisms of language change and development (Dombrovan, 2018). The main task of diachronic linguosynergetics is seen in capturing language in the state of change, when the language system follows a non-linear path, through numerous fluctuations and dissipation leading out of chaos to order and stability. Diachronic linguosynergetics aims at revealing and understanding the main laws of language evolution - the emergence of language, peculiarities of language non-linear development (gradual at times and sometimes precipitous), coherent behavior of its components and subsystems, the impact of external factors (including language contacts) on language structure, and the like.

The key concepts of synergetics as a holistic interdisciplinary methodological approach include, among others, the notions of a closed (isolated)/open system, linearity/non-linearity, self-organisation, dissipation, order (control) parameters, fluctuations and bifurcations, stability (equilibrium)/instability, an attractor, a fractal, and coherence. Most of these concepts are new to linguists because they were borrowed from mathematics and sciences. This makes it necessary to briefly define those of them that are employed in this article in order to ease the process of reading the latter.

The notion of linearity belongs to the paradigm of stability and equilibrium; it is displayed in the system's proportional reaction to the external disturbance. In other words, the behaviour of a linear system is fully predictable: knowing the initial conditions of a system, it is possible to foresee its further (linear) changes. 
By contrast, a non-linear system displays a wide variety of potential patterns of its behaviour because the "cause - consequence" principle does not apply. In mathematics, non-linearity is demonstrated by means of a particular type of equation with numerous variables and unknowns, which widen the spectrum of possible solutions depending upon the variables and/or coefficients. Methodologically, the concept of non-linearity reveals multiple alternatives of a system's trajectories of change and evolution.

Another important notion of synergetics is that of 'self-organisation' which implies the process and the result of coherent interaction of numerous components and parts of a system aimed at regulating the inner structure of the system. To function properly, a system must have all its components built-up and interconnected in a certain way, or order. External influence may cause re-arrangement of the system's components and changes in the behavioural pattern, including dissipation of the components that have lost their value and/or have become redundant. The loss of dual number of Old English personal pronouns is a shining example of dissipation in language. The meaning of a few other key concepts of synergetics employed in our article is revealed below.

\section{RESULTS AND DISCUSSION}

\subsection{A synergetic system: definition}

We will start with the notion of synergetics. The term "synergetics" is used to refer to a science of complexity that deals with different complex systems. A complex system is not only the one with a great many components. It is rather the way the components are linked to one another that matters. "System constituents are coupled to each other via some kinds of relation, so are not mere aggregates like piles of sand" (Bishop, 2011). The interconnection of the components within a system predetermines the system's behaviour. In H. Haken's (2000) words, "a modern definition (of a system - note by author) is based on the concept of algebraic complexity", i.e. it includes a sequence of data describing both the interconnected network and cooperativity of the system's elements and their complex behaviour. The most important features of a complex system include hierarchy (of levels and structures), irreversibility of processes, situatedness and stability, complex behaviour of its constituents and, as a result, of the whole system (Bishop, 2011). Taking everything in consideration, a synergetic system can be defined as a complex open system possessing the features of emergence, non-linearity of development, relative stability, dynamism, and adaptability to external circumstances.

A human language is a synergetic system, too. It represents a hierarchically organised megasystem, in which all the components are coherently linked on all its structural levels (the phonemic level, the morphemic level, the lexical level, and the syntactical level). A degree of complexity of any system is determined not only by the amount of its components, but also by a wide range of links and interactions among the components within the system, as well as by their ability to establish new (e.g., paradigmatic, syntagmatic, etc.) relations with other components and to fit in the existing links. The system's complexity involves its flexibility and dynamism.

It is obvious that language is always dynamic; it undergoes changes as a result of outer and inner influences. The language mega-system consisting of hierarchically structured and interconnected systems and subsystems is only relatively stable. To be precise, it is unevenly stable, for some parts of it can be in equilibrium at a given moment, while the other parts may not be. The language system is flexible and open to change. However, its subsystems change at a different rate. A history of the English language proves that phonetic processes are highly dynamic, while grammatical structures tend to remain more or less stable over the course of time. The dynamism, flexibility, and adaptability of a given system, as well as a complicated variety of links among the system's components - all these contribute into the notion of "complexity". 
That the language system has features of a synergetic system (openness, complexity, non-linearity, etc.) calls for a certain reconsideration of the notion of "system". In philosophy, a system is usually defined as a set of components closely interconnected with one another. Any system is seen as a certain whole, representing a unity of its parts. Traditional definitions of a language system, though slightly different, have much in common because they are grounded on the following four main concepts: unity, elements, structure and functions. A synergetic view of a system allows the inclusion of new senses into the notion of a system. It seems insufficient to imagine a system as a certain isolated set of components. The new definition of a system should include instability, openness, non-linearity, co-operation and co-evolution of its parts.

\subsection{Historical phonetics: a synergetic perspective}

The phonetic system of the English language has changed significantly over the last fifteen centuries. While Old English has much in common with other ancient languages of the Germanic group, it is in the Middle Ages and in the later period that English follows another trajectory of development. Observation of the historical development of the phonology of English has revealed that within the system of vowels, both qualitative and quantitative changes took place. Thus, vowels in unstressed positions gradually weakened, reduced and/or became lost. A number of vowels in stressed syllables developed into diphthongs, while existing diphthongs turned into monophthongs, and the vocalisation of consonants triggered the formation of new diphthongs. In the system of consonants, less drastic changes took place, the main of which being the process of assimilation.

A historical analysis of the evolution of the phonetic system of English has made it possible to propose the notion of "phase states of the phonetic system of language" (Dombrovan, 2018) in order to account for the directed chainlike and cyclic mode of phonemic alternations in the history of English. In what follows, the review of historical changes in English phonology is based on the data given in the most authoritative books on the history of the English language, among them (Jespersen, 1905; Brunner, 1950; Hock, 1991; Blake, 1996; Mitchell and Robinson, 1997; Blake, 2006; Baugh and Cable, 2006; van Gelderen, 2006; Mugglestone, 2006; Barber et al., 2009) and others.

A characteristic feature of the Old English vowel system is seen in the stability of back vowels and the instability of front vowels, especially of short front vowels that, in the course of time, became diphthongs. In Old English the following vowels occurred in a stressed position:

- $\quad$ short monophthongs (a, æ, e, i, o, u, y);

- $\quad$ long monophthongs ( $\overline{\mathrm{a}}, \overline{\mathrm{x}}, \overline{\mathrm{e}}, \overline{\mathrm{1}}, \overline{\mathrm{o}}, \overline{\mathrm{u}}, \overline{\mathrm{y}})$;

- $\quad$ short diphthongs (ea, eo, io, ie);

- $\quad$ long diphthongs ( $\quad \bar{a}$, ēo, $\overline{1} \mathrm{o}, \overline{1} \mathrm{e})$.

Old English diphthongs had the first element (i.e., the head) stressed. All languages of the Germanic group had short and long monophthongs, as well as short and long diphthongs. What seems specific to Old English is that certain short diphthongs developed from originally short monophthongs in a certain sound environment. However, by Middle English they had disappeared. Noteworthy is the fact that Old English vowels (which were Germanic by origin) did not always have regular correspondences in Gothic or Old High Germanic. In other words, as long ago as early Old English, the phonological system of English was beginning to split from the systems of cognate Germanic languages. In terms of synergetics, this must have been a bifurcation point, i.e., a peculiar branching or junction of the system's possible regimes of existence. One of the factors contributing to such phonological differentiation was the geographic remoteness of the Germanic tribes of Angles, Saxons, and Jutes, who settled on the British Isles, from their continental kinsmen. This gradually weakened communicative ties between representatives of the same lingual group. 
Let us consider some linguistic facts. In Old English before the nasal consonants [m] and [n], $i, u, o$ were used instead of Germanic $e, o$, $a$ respectively, as seen from:

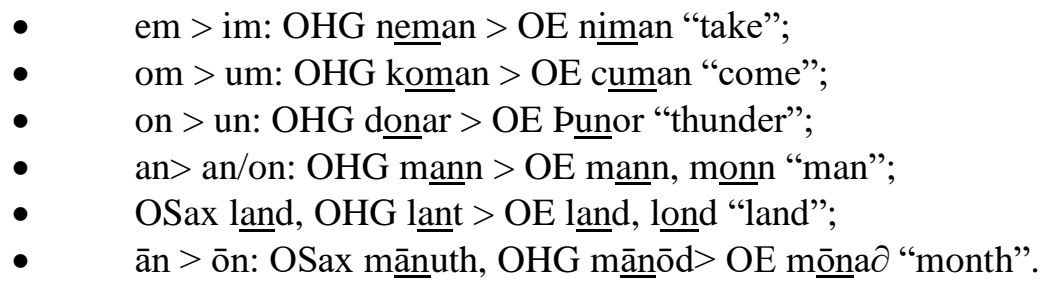

Another peculiarity of Old English vocalism consisted in the process of diphthongisation of front vowels before [rr], [r+consonant], [11], [l+consonant], [h]. This phonetic phenomenon is known as breaking. Among the most vivid examples are:

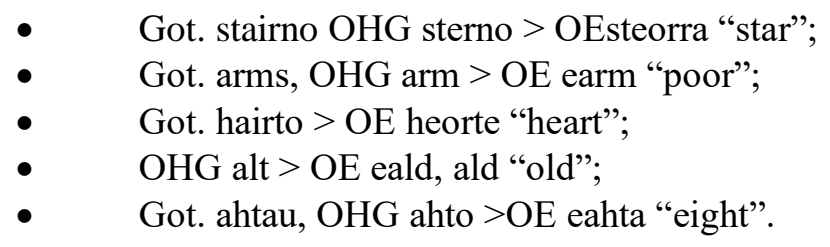

Unlike Gothic, Old High German and Old Saxon, in Old English the intervocalic h $[\chi]$, [ $\left.\chi^{\prime}\right]$ was lost, which lead to formation of a long diphthong, as in:

$$
\begin{aligned}
& \text { - } \quad \mathrm{a}+\mathrm{h} \downarrow+\mathrm{a} \rightarrow \text { èa: Got., OHG slahan - OE slēan "slay", OHG zahar - OE tēar "a tear"; } \\
& \text { - } \quad \mathrm{e}+\mathrm{h} \downarrow+\mathrm{a} \rightarrow \text { èo: OHG sehan - OE sê̄on "see", Got. tehan, OHG zehen - OE tê̄on "ten"; } \\
& \text { - } \quad \mathrm{i}+\mathrm{h} \downarrow+\mathrm{a} \rightarrow \text { èo: OSax thīhan - OE Pê̄on "thrive"; } \\
& \text { - } \quad \mathrm{e}+\mathrm{h} \downarrow+\mathrm{u} \rightarrow \text { èo: OHG swehur - OE swēor "husband's father". }
\end{aligned}
$$

In terms of synergetics, such a "loss" is regarded as a result of dissipation by the system of unnecessary elements whose functions and/or semantics reset to zero. Scholars have already noted that in different dialects of the Old English language phonetic changes were also different. Further evidence of the multidimensional development of the phonemic layer of the language was the so-called velar umlaut (the $8^{\text {th }}$ century) which consisted in diphthongisation of the front vowels $a, e, i$ in the syllable preceding the back vowels $u, o$, for example, in dialects of the Angles:

$$
\begin{aligned}
& \text { - } \quad \text { a > ea: caru > cearu "care"; alo } \partial>\text { ealu "ale"; } \\
& \text { - } \quad \text { i }>\text { eo: } \text { hefon > heofon "heavon"; } \\
& \text { i > io: } \text { silufr > siolufr > siolfor "silver". }
\end{aligned}
$$

From a synergetic perspective, the phonetic system of Old English, being a constellation of dialects spoken within kingdoms fighting for supremacy, was in a chaotic state, in non-equilibrium, as it was going through the stage of formation. This situation showed the absence of any external driving forces which could have regulated multidirectional fluctuations in order to set up common standards. Hence, the system's rushing about the phase space of potential states. During the Middle English period the following main changes in the system of stressed vowels took place:

- $\quad$ original long vowels were shortened before doubled consonants, as in: næddre $<$ OHG nātara, OSax. nādra "adder";

- $\quad$ OE short diphthongs ceased to exist;

- $\quad$ OE long diphthongs $\bar{e} a, \bar{e} o$, $\bar{l} o$ were lost; 
- $\quad$ OE monophthong $\alpha$ disappeared as well;

- $\quad$ remaining OE diphthongs became monophthongs (not later than the 11 th century);

- $\quad$ new diphthongs developed: $a i, e i, a u, o u, e u$;

- $\quad$ diphthongs $o i$ and $u i$ were borrowed from French.

The fact that Old English diphthongs [ie], [īe] were used alongside short and long monophthongs [y], [ȳ], [i], [ī] (as in: nieht, niht, nyht; geliefan, gelȳfan) was evidence of the process of simplification, and, by the beginning of Middle English, the above mentioned diphthongs were also lost. Once again, the system dissipated of certain elements but at the same time it acquired new ones through borrowing from outer systems or through formation from inner resources.

Using the data given in (Brunner, 1950; Smirnitsky, 1998; van Gelderen, 2006; Barber et al., 2009), the process of changes in the system of English stressed vowels can be generalised as in Tables 1 and 2. The asterisk $(*)$ here designates reconstructed phonemes.

Table 1. Changes in the system of stressed monophthongs in English.

\begin{tabular}{|c|c|c|c|}
\hline Stressed vowels & Germanic form & Old English & Middle English \\
\hline Short & $a>$ & $\mathrm{a}$ & $\mathrm{a}$ \\
\hline \multirow[t]{6}{*}{ monophthongs } & $* a>$ & $\mathfrak{x}$ & - \\
\hline & e $>$ & $\mathrm{e}$ & $\mathrm{e}$ \\
\hline & $i, e>$ & $\mathrm{i}$ & $\mathrm{i}$ \\
\hline & $\mathrm{u}>$ & o & o \\
\hline & $* \mathrm{u}, \mathrm{e}>$ & $\mathrm{u}$ & $\mathrm{u}$ \\
\hline & $\mathrm{u}>\mathrm{u}>$ & $\mathrm{y}$ & - \\
\hline Long & *ai > & $\overline{\mathrm{a}}$ & $\overline{\mathrm{a}}$ \\
\hline \multirow[t]{6}{*}{ monophthongs } & $* \overline{\mathrm{e}}>* \overline{\mathrm{a}}>$ & ǽ & - \\
\hline & $\overline{\mathrm{e}}>$ & $\overline{\mathrm{e}}$ & $\overline{\mathrm{e}}$ \\
\hline & $*_{\mathrm{e} i}>\overline{1}>$ & $\overline{1}$ & $\overline{1}$ \\
\hline & $* \overline{\mathrm{e}}>* \overline{\mathrm{a}}>\overline{\mathrm{o}}>$ & $\bar{o}$ & $\overline{\mathrm{o}}$ \\
\hline & $\overline{\mathrm{u}}>$ & $\overline{\mathrm{u}}$ & $\overline{\mathrm{u}}$ \\
\hline & $* \mathrm{u}>\overline{\mathrm{u}}>$ & ý & - \\
\hline
\end{tabular}

Table 2. Changes in the system of stressed diphthongs in English.

\begin{tabular}{|c|c|c|c|c|}
\hline Stressed vowels & Germanic form & Old English & \multicolumn{2}{|c|}{ Middle English } \\
\hline \multirow[t]{4}{*}{ Short diphthongs } & $\begin{array}{c}\mathfrak{x}>\mathfrak{x o}> \\
\text { also: a >ea }>\end{array}$ & ea & - & $(>\mathfrak{x}>\mathrm{a})$ \\
\hline & e > & eo & - & $(>\ddot{o}>\mathrm{e})$ \\
\hline & $\mathrm{i}>\mathrm{iu}>$ & io > eo & - & \\
\hline & e $>$ ie $>$ & ie & - & \\
\hline \multirow[t]{4}{*}{ Long diphthongs } & $\begin{array}{c}\text { *aů > ǽo > } \\
\text { also: ǽ> ǽo > }\end{array}$ & èa & - & $(>\mathfrak{x}>\overline{\mathrm{e}})$ \\
\hline & $\overline{\mathrm{e}}>$ & èo & - & $(>\ddot{\mathrm{o}}:>\overline{\mathrm{e}})$ \\
\hline & $\overline{1}>\overline{1} \mathrm{u}>$ & 1̄o $>$ eō & - & $(>\overline{\mathrm{e}})$ \\
\hline & $\overline{\mathrm{e}}>\mathrm{ie}>$ & $\overline{1} \mathrm{e}$ & - & \\
\hline \multirow[t]{7}{*}{ Normal diphthongs } & & & ai & \\
\hline & & & $\mathrm{au}$ & \\
\hline & & & ou & \\
\hline & & & eu & \\
\hline & & & iu & \\
\hline & & & oi & \\
\hline & & & ui & \\
\hline
\end{tabular}


The emergence of new diphthongs is traditionally connected with the vocalisation of $w$ and of the palatal and velar $g$ following a vowel and with development of glides between vowels and the following palatal or velar $\mathrm{h}[\chi]$. As a result of the vocalisation of the palatal $g$ and the appearance of glides before the palatal $\chi$ there developed diphthongs with the second element $i$. Diphthongs with the second element $u$ emerged as a result of vocalisation of $w$, the velar $g$ and the appearance of glides before velar $\chi$. Karl Brunner gave the following examples:

- $\mathrm{OE} æ+$ palatal g = ai: OE dæg $\rightarrow$ MidE dai “day";

- OE a + palatal $\mathrm{g}=\mathrm{au}:$ OE dragan $\rightarrow$ MidE drauen, drawen "draw";

- OE o + palatal $g=$ ou: OE boga $\rightarrow$ MidE boue, bowe "bow".

The process of the loss of old diphthongs and the simultaneous formation of new diphthongs refers to Late Old English and Early Middle English. Using the meta-language of synergetics, it is possible to state that within the given time period the phonological system of language was going through a bifurcation zone, dissipating of old components and acquiring new ones. The loss of a number of phonemes violated the symmetry of the phonological system, which caused a rapid restructuring of the system in order to achieve equilibrium.

Of special interest is the fact (Table 2) that there is a certain cycle in the chainlike change of some phonemes. Thus, for instance, the Germanic form $e$, which gave the diphthong $e o$ in Old English, in Middle English returns through intermediate stages to its original form. The same is observed with the long $\bar{e}$. In terms of synergetics, such a cyclic character of changes can be interpreted as the movement of the system around the definite "space of states".

Obviously, the trajectories of phonetic changes, in spite of their variety, do have quantitative limits of possible states and stages of transition to the latter. This partially explains the fact that, as observed by (Otto, 1905; Paul, 2002), vowel $a$, though able to change gradually into any other vowel, at first develops either towards $i$, or towards $u$. We think that one of the factors limiting any stochastic rushing of the system around the space of states lies within the physiological peculiarities of sound production, including the type of a syllable (stressed or unstressed), the force of its articulation, as well as the place of its articulation, etc. We argue that there exists "a space of states" for the phonetic system of language, in which any changes within consonants or vowels are not occasional but of a regular character, determined by the peculiarities of a given language. This suggestion is supported by directionality of qualitative changes in pre-written Old English.

A good example is the phenomenon of $i$-umlaut which consisted in the following: back or low vowels (short and long) $u, o, a$ in the pre-position to $i$ partially mutated, moved forward and raised, changing into $y, e, c e$ (short and long, respectively) (Hogg, 2005; van Gelderen 2006; Barber et al., 2009). That change is seen in the following pairs of words, such as Old English full and fyllan (Modern English full and fill), Old English fox and fyxen (Modern English fox and vixen), Old English föd and fêdan (Modern English food and to feed), Old English $t \bar{o} p$ and tēp (Modern English tooth and teeth), Old English man and menn (Modern English man and men), and others. The following Table 3 shows directionality of changes.

Table 3. Directionality of qualitative changes.

\begin{tabular}{lll}
\hline Directionality of changes & from & to \\
\hline forwarding & $\mathrm{a}$ & $\mathfrak{x}$ \\
raising & $\mathfrak{}$ & æ: \\
forwarding & $\mathrm{a}:$ & $\mathfrak{x}:$ \\
forwarding & $\mathrm{o}$ & $\mathrm{oe} \rightarrow \mathrm{e}$ \\
raising & $\mathrm{e}$ & $\mathrm{i}$ \\
forwarding & $\mathrm{o}:$ & $\mathrm{oe}: \rightarrow \mathrm{e}:$ \\
forwarding & $\mathrm{u}$ & $\mathrm{y}$ \\
\hline
\end{tabular}




forwarding $\quad \mathrm{u}: \mathrm{y}: \rightarrow \mathrm{i}:$

Needless to say, the phonetic changes did not take place simultaneously or regularly on different territories of the British Isles. Thus, the systems of vowels of northern and southern dialects of the 12th and early 13th centuries were slightly different, for in southern dialects the long vowel [a:] was absent, while in the northern dialects the long vowel [o:] was missing (Figure 1):

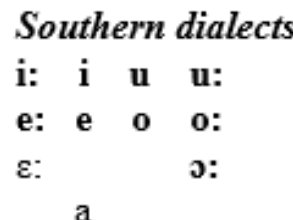

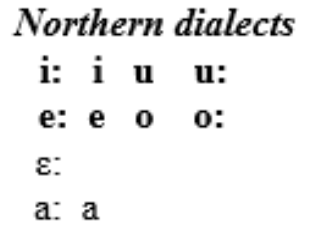

Figure 1. Differences in the systems of vowels in Middle English northern and southern dialects.

Source: R. Lass (2006).

The 13th century witnessed quantitative changes of vowels, namely lengthening of the short low [a] and middle [e] and [o] in the initial open syllable of two-syllabic words, as in:

- $\quad$ OE $[a]>\operatorname{MidE}[a:]:$ nama [nama] $>$ nāme [namə] > [na:mə];

- $\quad \mathrm{OE}[\mathrm{e}]>\operatorname{MidE}[\varepsilon:]$ : mete [mete] $>$ mete $[\mathrm{m} \varepsilon: \mathrm{te}]>[\mathrm{m} \varepsilon: \mathrm{t}$ ] $]$

- $\quad$ OE [o] $>$ MidE [o:]: nosu [nosu] $>$ nose [nosə] $>$ [no:zə].

The short high [i] and [u] became longer as well and developed into [e:] and [o:] correspondingly. Examples:

- $\quad$ OE [i] > MidE [e:]: wicu [wiku] > [wikə] > weeke [we:kə];

- $\quad$ OE $[\mathrm{u}]>$ MidE [o:]: wudu [wudu] > [wudə] > wode [wo:də].

R. Lass (2000; 2006) represents the phonetic process of lengthening vowels in open syllables graphically as follows (Figure 2).

Southern dialects

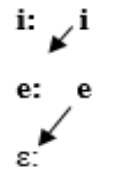

a: $\leftarrow \mathrm{a}$
Northern dialects

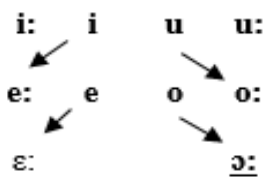

a: $\leftarrow \mathrm{a}$

Figure 2. Quantitative changes of vowels (lengthening in open syllables) in southern and northern dialects in the Source: R. Lass (2006). 13th century.

The scheme shows identical shifts of vowels as a result of the quantitative changes in southern and northern dialects. This fact leads to an idea of a directed chainlike mode of changes in the phonetic space of the language system. In our opinion, the phonetic space of a certain language system has a (potentially limited) number of possible trajectories of movement, so to speak, 'channels' of changes, which keep the system from chaotic rushing or uncontrolled positional skipping. Another important consequence of the phenomenon of lengthening in an open syllable is the appearance of "missing" phonemes in the dialects 
under consideration (Figure 2). The two territorially remote dialect areas "levelled" their systems of vowels, which showed that the phonetic system of English was approaching the state of equilibrium. However, equilibrium does not mean "immobility". It is rather a dynamic stability when the system suffers insignificant fluctuations.

The phonetic system of any language is subject to endless impacts from external factors. Sometimes, single changes within a system are able to generate a chainlike restructuring of the whole system. A vivid example of gradual changes is represented by the phenomenon of the Great Vowel Shift, which began in approximately the 15th century and lasted for at least centuries. Most scientists believe that on the whole this phonetic process ended in the 17th century. However, there exists a view point that the Great Vowel Shift is still going on at present (Kerswill, 2002). The Great Vowel Shift involved changes in the quality of all the long vowels. Long vowels became narrowed, while long [i:] and [i:] developed into diphthongs. The Table 4 below that is based on the one in (Buniiatova, 2011) shows the series of changes under consideration.

Table 4. The Great Vowel Shift in English (15th - 17th century).

\begin{tabular}{|c|c|c|}
\hline Vowels & MidE $\Rightarrow$ Early MnE & $\mathrm{MnE}$ \\
\hline \multirow[b]{2}{*}{ Front vowels } & /i:/ > /ii/> /ei/ > /æi//> /ai/ & $\rightarrow$ /ai/ \\
\hline & $\begin{array}{l}\text { le:/ > /æ:/ > /E:/ > /i:/ } \\
\text { /æ:/ }\end{array}$ & $\begin{array}{l}\rightarrow / \mathrm{i}: / \\
\rightarrow \mathrm{e}: / \rightarrow / \mathrm{i}: /\end{array}$ \\
\hline Middle vowels & /a:/> /æ:/ > /ع:/ > /e:/ > & $\rightarrow / \mathrm{e}: /$ \\
\hline \multirow[t]{2}{*}{ Back vowels } & /o:/ & $\rightarrow / \mathrm{u}: /$ \\
\hline & $\mathrm{lau} /$ & $\rightarrow / \mathrm{o}: /$ \\
\hline
\end{tabular}

These changes in pronunciation were not followed by changes in writing, because by that time spelling had already been established. In terms of synergetics, orthography as an open dynamic system of language had reached equilibrium long before pronunciation of words became stabilised, hence the discrepancy between the reading and writing rules of modern words.

In the Early Modern English period, new diphthongs appeared as a result of vocalisation of [r] at the end of a word and before a consonant (because a vowel could hardly have been narrowed before [r]). Cf. moor [mo:r] > [muə], but moon [mo:n] > [mu:n]. This phonetic process, as well as the Great Vowel Shift, represents a gradual type of revolutionary change within the given system. The gradual character of the appearance of new diphthongs due to the vocalisation of $[\mathrm{r}]$ is seen from the examples below:

- $\quad[\mathrm{e}:]>[\mathrm{i}:]>[\mathrm{i}$ ] $]$, e.g. here, steer;

- $\quad[\varepsilon:]>[\mathrm{e}:]>[\varepsilon ə]$, e.g. wear, bear;

- $\quad[\varepsilon:]>[\mathrm{e}:]>[\mathrm{i}]$, e.g. clear, fear;

- $\quad[\mathrm{a}:]>[\mathrm{ei}]>[\varepsilon ə]$, e.g. care, fare;

- $\quad[\mathrm{o}:]>[\mathrm{u}:]>$ [uə], e.g. poor, moor.

The quantitative changes of vowels in Middle English and Early Modern English (including the lengthening of the short vowels $a$ and $o$ before $[\mathrm{f}],[\theta],[\mathrm{s}],[\mathrm{f}],[\mathrm{t}]]$ and the shortening of the long $\bar{e}$ and $\bar{o}$ before combinations of consonants, in the third last syllable, and in monosyllabic words, etc.) are not occasional but determined by certain tendencies of development of short and long vowels (Brunner, 1950).

The fact that certain tendencies do exist in the change of the quality and/or quantity of the sound supports my suggestion that all phonetic changes occur within the certain space of states of the language system. We think that the space of states of the phonetic system of language is limited by physiological peculiarities of sound production. The above-mentioned cyclic character in the shift of vowels supports my view that the 
possible ways of changing within the system are numerous, but not infinite. The suggested notion of the space of states of the phonetic system brings us to understanding of the existence of transition stages, on the one hand, and the absence of any skipping of intermediate stages, on the other. So far, the main historical changes within vowels in stressed syllables (which were also root morphemes) have been dealt with. Now let us outline the principal changes of vowels in unstressed syllables.

A peculiarity of Old English (as compared, for instance, with $\mathrm{OHG}$ ) was that in un stressed syllables there were no long vowels (they had been shortened) or diphthongs (they had become monophthongs). Short vowels in unstressed syllables partially weakened: $a>e ; i>e ; u>o>a$. Sometimes unstressed vowels $e$, $a, o$ was used interchangeably, and later they reduced to the weak $\partial$. At the end of a two-syllable word after a long-stressed root syllable, vowels would reduce and be lost. Short vowels in the position of being after a long-stressed syllable and before an unstressed syllable became syncopated, as in: OE magden "maiden" (Cf OHG magatīn); Genitive Singular hēafdes from Nominative hēafod "head"; Genitive micles from Nominative micel "much".

The development of new unstressed vowels, as we see it, was of compensating character, for they appeared before the vowels (usually $\mathbf{r}$ and $\mathbf{l}$ ) after which final vowels were usually lost. For example: OE winter (Cf. Goth. wintrus); OE hungor (Cf. OIcl. hungr). This tendency was going on in Middle English, which is shown in the forms: burowe, burewe, borough (< OE burg, MnE borough); swalowe, swalewe (< Angl. swalwe, MnE swallow).

Obviously, the weakening and subsequent loss of vowels in unstressed positions brought about an asymmetry in the phonetic system of language, which might have led the system to non-equilibrium. To gain stability, the language as a synergetic system sets off mechanisms of self-organisation, which in our case is the compensating development of vowels in pre-final position (i.e. before the final consonant of a word). This kind of restructuring not only stabilises the system but also contributes to the appearance of new qualities in the system. On the whole, the renewed system evolves to equilibrium.

In Middle English, vowels in unstressed syllables went on weakening, and the final $a, o, u$ gradually reduced to $e$ [ə]. As H. Hock (1991) rightfully points out, "word-final position is as vulnerable an environment for vowels as it is for consonants and consonant clusters". Such a tendency can be explained on the basis of the word energy structure which is characterised by an ascending-descending energy pattern. The end of a word or a word-combination is far less tensed when compared with its initial syllable(s) (Taranets, 2009).

Tradition has it that in the 12th century the final $-e$ is beginning to disappear, which is reflected both in writing and rhyming. It is well known that in the works by Geoffrey Chaucer (the 14th century) the final $-e$ could be either read or not, depending upon the rhythmic organisation of the verse (Chaucer, 1996). In his "The Canterbury tales", one can come across the possessive pronoun "mine" that is read differently within the same line, as in: "Mine hert is also mouled as mine heeres" ["The Reeve's Prologue", line 16], "my heart is mouldy (=aged) as my hair", where, in the combination "mine hert", it is pronounced as [mi:n], i.e., without the final sound; however, in the combination "mine heeres", it is read: ["mi:nə].

The final silent $-e$ was possibly omitted, which, in its turn, led to a variety of spelling forms. Thus, in "The Canterbury Tales" we come across the following pairs of words:

wold - wolde:

And gladly wold he lern and gladly teeche [The General Prologue, line 308];

She was so charitable and so pitous

She wolde weep if that she saw a mous

Caught in a trap, if it were deed or bledde [ibidem, lines 143-145]; 
coud-coude:

He coud in litel thing have suffisaunce [ibidem, line 490];

He moste preech and well affile his tonge

To winne silver, as he full well coude -

Therefore, he song the murrierly and loude [ibidem, lines 712-714];

Short was his gown, with sleeves long and wide.

Well coud he sits on horse and faire ride.

He coude songes make, and well endite [ibidem, lines 93-95].

tell-telle:

By God, I hope I shall you tell a thing

That shall by reson been at your liking!

For though myself be a full vicious man,

A moral tale yet I you telle can [The Pardoner's Prologue, lines 129-132].

Obviously, Geoffrey Chaucer (although quite unaware of it) "caught" the instability phase of the phonetic system of the English language of his time and reflected it in his poems (Chaucer, 1997). At the beginning of the Middle English period the suffix of abstract nouns still retained its two Old English forms with a dialectal difference, -nis(se) and -nes(se). However, language, being a synergetic system, tends not only to avoid any excess in elements but also to dissipate the unnecessary. Unification and standardisation of orthographic norms ousted parallel means of expression, and only one form of a few (here -nes(se), Modern English -ness) has survived. The choice of the form -nes(se), and not -nis(se), was not determined by any factors. From a synergetic view point, the development and functioning of an evolving open system is described by a number of variables in an equation. These variables contribute to a wide choice of possible ways of further development of the given synergetic system. The same is true with regard to language as an open developing system. Any human language represents a complex system with a number of variables "working" on its different levels and within its numerous subsystems. It is their "work" that is responsible for alternatives of evolution and the system's final choice of the trajectory of development.

\subsection{Historical changes within consonants}

The Old English phonetic system included the following consonants:

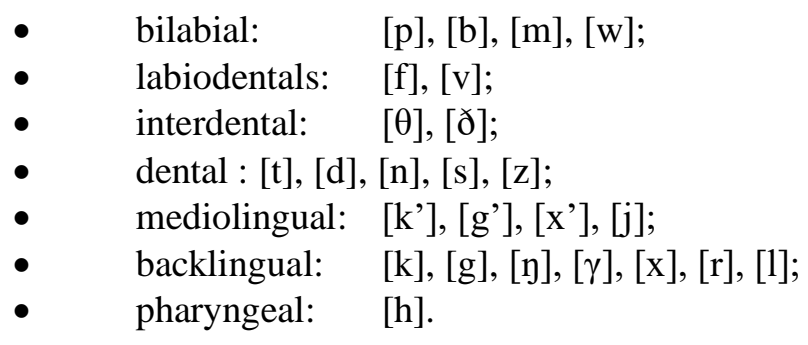

A peculiar characteristic of the consonant system in Old English was the phenomenon of gemination lengthening of consonants as a result of the assimilation of [j] with the preceding consonant. Hence comes the division of Old English consonants and Middle English consonants into short and long ones depending

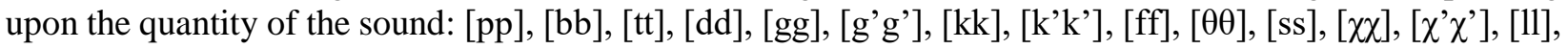
[rr], [mm], [nn]. Geminates are found in the intervocalic position, e.g.: OE sittan <*setjanan, Goth. satjan, OIcel. sitia "to sit"; OE tellan < *taljanan, OIcel. telia "to tell". 
In writing, the contrast between short and long consonants was marked by doubling the corresponding letters. JAW Bennett found out that this unique system of spelling was developed and used in many poems. Here is an extract from this piece with a word-for-word translation:

$\mathrm{Nu}$ wile icc here showenn $3 u w$;

(Now want I here to show/tell you)

Off ure laffdiz marze.

(Of our Lady Mary)

Off - hu zho barr Pe laferrd crist;

(of - how she gave birth to Lord Crist)

Att hire rihhte time.

(at her right time)

Swa Patt zho Pohh Paraffterr wass;

(So that she was thought after that)

Azzmazzdenn Dweorrt üt clene!

(Always Maiden completely pure!) .

At the end of the Middle English Period, doubled consonants were simplified, which was reflected in the pronunciation and spelling of the words. Another interesting fact is that in Old English there existed palatal consonants which became affricates in Middle English: voiceless [ $\mathrm{t}] \mathrm{f}$ and voiced [d3]. This process is known as assibilation. Examples: OE cild [k'i:ld] > MidE child [ $\mathrm{t} f \mathrm{i}: \mathrm{ld}]>\mathrm{MnE}$ child [t $\mathrm{f}$ arld]; OE scip [sk'ip] $>$ MidE scip, ship [ $\left.]_{\mathrm{ip}}\right]>\mathrm{MnE}$ ship [ $\left.\int_{1 \mathrm{p}}\right]$.

Assibilation is worth noting here because, in the result of this process, the mediolingual sounds [k'], [k' $\mathrm{k}$ '], [g'], [g'g'] "moved" forward and became fronted. Obviously, the "forward" movement for consonants and the "forward-and-up" movement for vowels are the main trajectories of phonetic changes within the space of states of this subsystem of the English language.

One more phonetic phenomenon in Old English should be mentioned here, namely "metathesis", which was realised in replacing the letter $\mathrm{r}$ and the corresponding sound, which gave Pirda and Pridda "third"; irnan, $\underline{y}$ rnan and rinnan, "to run". In Modern English, it is observed within three and third. The phonetic essence of metathesis is not at all disclosed. Some scholars connect it with certain slips of the tongue, while others think that this process is unavoidable in borrowing new words when the order of sounds is far more difficult for a recipient than their quality and/or quantity. The synergetic paradigm enables us to understand metathesis as the system's fluctuation while in the phase shift, i.e., in the stage of transition towards a new stable state of the given system. The alternatives that appear (here: $r$ before a vowel // $r$ after a vowel) can be regarded as certain attractors to which the system is being drawn now and then.

The phonetic processes of assimilation, of assibilation, and those of metathesis represent the phasal microspaces of the phonetic system of language. Within these spaces the corresponding language units follow definite trajectories (as in the case of the vowel shift or the assibilation of consonants). Any chaotic or irregular movements "aside" are hardly possible, for the trajectories direct the system into the definite route. At the same time, the system, which is dynamic, is also unstable because of the inherent asymmetry. Dynamism and non-equilibrium enable the system to move from one attractor to another. Here the function of attractors is performed by variants of phonemes, combinations of phonemes, etc., from which the system is to choose. However, the choice made is usually both inexplicable and unpredictable.

Being dynamic, phasal states of a system sooner or later shift and change one another, thus forming the basis for a cyclic mode of the development of the given system. Such a shift of the states at the micro-levels of the system accounts for the following phonetic change: $[\partial] \rightarrow[d],[d] \rightarrow[\partial]$. Researchers have noticed that the Old English sound [ $\partial]$ before $m, n, l, r$ changed into [d] in early Middle English. This gave MidE

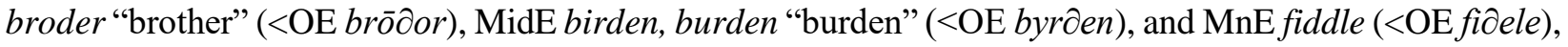




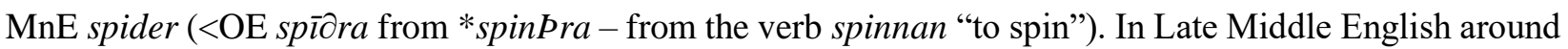
the 15th century the sound [d] after a vowel and before r changed into [ $\partial]$, which explains the modern forms: mother ( $<\mathrm{OE}$ mōdor), father ( $<\mathrm{OE}$ fader), gather ( $<\mathrm{OE}$ gadrian, MidE gaderen), together ( $<\mathrm{OE}$ togadere), weather ( $\angle \mathrm{OE}$ weder), wither ( $\angle \mathrm{OE}$ widereian), including largely obsolete adverbs hither "here" $(<\mathrm{OE}$ hider) and thither "there" ( $<$ OE Pider), remaining in the set expression hither and thither (Brunner, 1950).

An earlier example of a chain-like change in the system of phonemes is given by a complex of interconnected changes of Indo-European consonants in Germanic languages which is known as The First Consonant Shift, or Grimm's Law. The famous German philologist J. Grimm suggested an explanation for certain regular correspondences between the following groups of consonants in Germanic languages and other Indo-European languages of the non-Germanic group. According to J. Grimm, Indo-European aspirates, $b h, d h$ and $g h$ correspond to Germanic voiced stops $b, d$ and $g$; Indo-European voiced stops, $b, d$ and $g$ correspond to Germanic voiceless stops $p, t$ and $k$; and Indo-European voiceless stops, $p, t$ and $k$ correspond to Germanic voiceless fricatives $f, \theta$ and $h$. The general direction of the consonant shift can be shown in the following way in Table 5.

Table 5. The First Consonant Shift.

\begin{tabular}{lccc}
\hline aspirates $\rightarrow$ & voiced $\rightarrow$ & voiceless stops $\rightarrow$ & voiceless fricatives \\
\hline bh & $\rightarrow \mathrm{b}$ & $\rightarrow \mathrm{p}$ & $\rightarrow \mathrm{f}$ \\
$\mathrm{dh}$ & $\rightarrow \mathrm{d}$ & $\rightarrow \mathrm{t}$ & $\rightarrow \theta$ \\
$\mathrm{gh}$ & $\rightarrow \mathrm{g}$ & $\rightarrow \mathrm{k}$ & $\rightarrow \mathrm{h}$ \\
\hline
\end{tabular}

In Middle English, consonants are lost in many distributional patterns, the main ones being:

- $\quad w$ was lost before $u$, as in: MidE suche, such $(<\mathrm{OE}$ swylc);

- $\quad l$ was lost before $[\mathrm{t}]$ ], as in: MidE swich, suche, such $(<\mathrm{OE}$ swylc);

- $\quad$ the initial $h$ went out of use in words beginning with $h l$-, $h n-, h r-$, e.g.: MidE lōrd (<OE hläford), MidE nute ( $<\mathrm{OE}$ hnutu), MidE ring ( $<\mathrm{OE}$ hring);

- $\quad$ in the Early New English period, the letter $l$ became silent before $k, m, f$ and $v$, as in: talk, palm, calf, halves;

- $\quad$ also, $l$ was not pronounced before - $d$ in commonly unstressed modal verbs should, would and could; - certain combinations of consonants became simplified, e.g.: [mb]> [m] (lamb, climb); [mn]> [m] ( solemn, column, autumn); [stl] > [sl] (castle, whistle); [stn]> [sn] (listen, fasten), etc.

In the terms of synergetics, the fact that the language system got rid of certain elements is considered as a dissipative process. Indeed, the system has withdrawn certain elements from its boundaries. Moreover, dissipation is sometimes seen as an analogue of the biological factor of natural selection. The fact that dissipative processes at the phonetic level are possible and do happen proves that language is an open synergetic system.

\section{CONCLUSIONS}

A synergetic system possesses such characteristics as openness, adaptability, dynamism, self-organisation, non-linearity, all of them contributing to the system's complexity. Language is a synergetic system, too. It can be modelled as a megasystem of interconnected systems and sub-systems. The phonetic system of language belongs to synergetic systems because it changes according to common principles of development of complex systems.

However, changes in the phonetic system are neither chaotic nor random. They are preconditioned by the features of the system. The trajectories of changes are determined by what we call "the space of states" of 
the synergetic system. The cyclic character in the shift of vowels and consonants demonstrates that the possible ways of changing within the system may be numerous, but not infinite or accidental. The suggested notion of the space of states of the phonetic system reveals the existence of transition stages, on the one hand, and the absence of any skipping of intermediate stages, on the other. The notion of dissipation is used to account for the system's getting rid of certain elements, as was shown with the historical development of the system of consonants in English. The prospect of further studies lies within comparative linguistics in order to verify the ideas and obtained data on the material of other languages.

\section{REFERENCES}

Barber, Ch., Beal, J. C., \& Shaw, Ph. A. (2009). The English language: A historical introduction. Cambridge, England: Cambridge University Press, 285 p.

Baugh, A. C., Cable, Th. (2006). A history of the English language. London, Great Britain: Routledge, 620 p.

Bennett, JAW, Gray, Douglas (ed.). (1986). Middle English literature. Oxford: Clarendon Press. 330 p.

Bishop, R. C. (2011). Metaphysical and epistemological issues in complex systems. In C. Hooker (Ed.), Philosophy of Complex Systems. Amsterdam, Netherlands: Elsevier B.V., 106-136.

Blake, N. (2006). The Cambridge history of the English language. Cambridge, England: Cambridge University Press, $321 \mathrm{p}$.

Blake, N. F. (1996). A history of the English language. London, Great Britain: MacMillan Press Ltd., 518 p.

Brunner, K. (1950). The English language: Its historical development. General: Sound history. Halle, Germany: Niemeyer, 1, 30-41.

Buniiatova, I. R. (2011). Evolution of dynamic systems. Bulletin of V.N. Karazin Kharkiv National University. Series "Romano-Germanic Philology. Methods of Teaching Foreign Languages", 954 p.

Burrow, J. A., Turville-Petre, Th. (1997). A Book of Middle English. Oxford, England: Blackwell Publishers, 330 p.

Chaucer, G. (1996). The Canterbury tales. A selection. London, Great Britain: Penguin Books, 242 p.

Chaucer, G. (1997). The parliament of fowls. In J.A. Burrow, and Th. Turville-Petre (Ed.), A Book of Middle English. Oxford, England: Blackwell Publishers, 262-286.

Dombrovan, T. (2018). An introduction to linguistic synergetics. Cambridge, England: Cambridge Scholars Publishing, $150 \mathrm{p}$.

Haken, H. (1977). Synergetics. An introduction. Berlin, Germany: Springer-Verlag, 335 p.

Haken, H. (1987). Advanced synergetics. Berlin, Germany: Springer-Verlag, 316 p.

Haken, H. (2000). Information and self-organisation: A macroscopic approach to complex systems. Berlin, Germany: Springer-Verlag, $243 \mathrm{p}$.

Hock, H. H. (1991). Principles of historical linguistics. Berlin, Germany: Mouton de Gruyter, 744 p.

Hogg, M. (2005). The Cambridge history of the English language. Cambridge, England: Cambridge University Press, $588 \mathrm{p}$.

Jespersen, O. (1905). Growth and structure of the English language. Leipzig, Germany: Teubner, - $260 \mathrm{p}$.

Kerswill, P. (2002). Models of linguistic change and diffusion: New evidence from dialect levelling in British English. Reading Working Papers in Linguistics, 6, 187-216. 
Lass, R. (2000). The Cambridge history of the English language. Cambridge, England: Cambridge University Press, $771 \mathrm{p}$.

Lass, R. (2006). Phonology and morphology. In N. Blake (Ed.), The Cambridge History of the English Language. Cambridge, England: Cambridge University Press, 23-155.

Mitchell, B., Robinson, F. C. (1997). A guide to Old English. Oxford, England: Blackwell Publishers Ltd, 422 p.

Mugglestone, L. (2006). The Oxford history of English. Oxford, England: Oxford University Press, 485 p.

Smirnitsky, A. I. (1998). Old English. Moscow, Russian Federation: MSU named after M.V. Lomonosov, 630 p.

Taranets, V. G. (2009). Trypillia substrate: The origin of ancient European languages. Odesa, Ukraine: ORIDU NADU, 298 p.

van Gelderen, E. (2006). A history of the English language. Amsterdam, Netherlands: John Benjamins Publ, 436 p.

von Bertalanffy, L. (1968). General system theory. New York, USA: George Braziller, 389 p.

von Bertalanffy, L., Sutherland, J. W. (1974). General systems theory: Foundations, developments, applications. IEEE Transactions on Systems, Man, and Cybernetics, 4(6), 592-592.

\section{SEMBLANCE OF THE AUTHORS}

Tetiana I. Dombrovan: She is a Full Doctor in Philology, Professor at the Department of English Philology and Translation Studies of Odessa National Polytechnic University. Her fields of scientific interests include methodological problems of sociological research, media education, sociology of mass media and communication.

Olena M. Mitina: She is a PhD in Philology, Associate Professor at the Department of English Philology and Translation Studies of Odessa National Polytechnic University. Her areas of research interest include public relations, development communication, and culture studies.

Lada M. Rostomova: She is a PhD in Psychology, Associate Professor at the Department of English Philology and Translation Studies of Odessa National Polytechnic University. Her fields of scientific interests include philosophical issues of communication theory, media and information literacy, and philosophy of history.

Iryna V. Slobodzowa: She is a PhD in Philology, Associate Professor at the Department of German Philology and Translation Studies of Odessa National Polytechnic University. Her areas of research interest include social media, political communication, and media psychology.

Khrystyna T. Pavliuk: She is an Assistant at the Department of English Philology and Translation Studies of Odessa National Polytechnic University. Her areas of academic interest are culture studies and participatory development communication. 